\title{
Forthcoming Books of Science
}

\section{Agriculture, Horticulture and Forestry}

Crosby Lockwood \& Son, Ltd. Intensive Salad Production-C. P. Quarrell. Practical Lawn Craft-R. B. Dawson.

English Universities Press, Ltd. Fruit Growing up to Date-W. E. Shewell-Cooper. Principles and Practice of Poultry Husbandry-T. Newman.

P. S. KING \& Son, LTD. Land Reclamation and Drainage in Italy-C. Turnor. The Soil and Social Reclamation-G. C. Watson.

McGraw.Hill Publishing Co., Ltd. An Introduction to American Forestry-Shirley Allen. Statistical Technique in Agricultural Research-D. D. Paterson.

Macmillan \& Co., Ltd. Silage and Crop ProductionDr. S. J. Watson. Grassland Management for the Practical Farmer-W. R. Peel.

Thomas Murby \& Co. An Outline of Forestry-T. Thomson and R. M. K. Jerram. Elementary Forest Mensuration-R. M. K. Jerram.

Putnam \& Co., Ltd, Forest Trees of the Pacific Coast -W. A. Eliot.

Williams \& Norgate, Ltd. Hardy Bulbs, vol. 3, Liliaceæ-Lieut.-Colonel C. H. Grey.

\section{Archæology and Ethnology}

George Allen \& Unwin, Ltw. Language Hunting in the Karakoram-E. O. Lorimer.

B. T. BATsFord, LTD. Old English Customs and Ceremonies-F. J. Drake-Carnell.

G. Bell \& Sons, Ltd. Tools and the Man-Dr. W. B. Wright.

Cambridge University Press. Prehistoric Macedonia -W. A. Heurtley.

Gerald Duckworth \& Co., Ltd. The Maya, American and Other Early Civilizations-T. Gann.

Hodder \& Stovarton, Ltd. The Ancient World-

J. M. Todd.

McGraw-Hill Publishing Co., Ltd. A History of

World Civilization-J. E. Swain.

Macmillan \& Co., Ltd. Anthropology and the Apocalypse-Dr. V. Burch. Cylinder Seals-Dr. H. Frankfort.

Methoen \& Co., Ltd. Gypsies : their Lives and their Customs-Martin Block.

\section{Astronomy}

Grorae Allen \& Unwin, Ltd. Copernicus, the Founder of Modern Astronomy-A. Armitage.

Cambridge University Press. Stellar Dynamics-

Prof. W. M. Smart.

English UnIversities Press, Ltd. The Beginning of All Things-Dr. H. Spencer Jones.

\section{Biology}

Grorge Allen \& Unwin, LtD. Introduction to Modern Genetics-C. H. Waddington. Mathematical Methods for Medical and Biological Students-Prof. G. Dahlberg.

D. Appleton-Century Company. Medical Bacteriology -D. L. Belding. Essentials of Pathology-Dr. L. W. Smith and Dr. E. S. Gault. Life in an Air CastleF. M. Chapman.
Edward ARnold \& Co. An Introduction to Industrial Mycology-G. Smith.

B. T. BATSFORD, LTD. Wild Animals in BritainFrances Pitt.

Cambridge University Press. Wild Country-Dr. F. Fraser Darling. Cattle Fodder and Human NutritionProf. A. I. Virtanen. Theories of Sensation-A. F. Rawdon-Smith. Evolution of Genetic Systems-Dr. C. D. Darlington. Form and Causality in Early DevelopmentA. M. Daleq.

Chapman \& Hall, Ltd. Science of Animal LifeProf. A. W. Lindsey.

Gerald Duckworth \& Co., Ltd. Birds through the Year-"Fish-Hawk".

English UntVkrsities Press, Ltd. Man against Microbe-Dr. J. W. Bigger. Ascaris: the Biologist's Story of Life-R. Goldschmidt.

EYRE \& SPOTtiswoode, Ltd. Bird Sketches and Some Field Observations-Philip Rickman.

W. Heffer \& Sons, Lrd. The Microbe ManEleanor Doorly.

William Heinemann, Ltd. Birds as Animals-James Fisher. Clinical Studies in Lactation-H. K. Walker.

Longmans, Green \& Co., Ltd. The Control of the Circulation of the Blood-Prof. R. J. S. McDowall.

McGraw-Hill Publishing Co., Ltd. Fundamental Principles of Bacteriology-A. J. Salle. Quantitative Zoology-G. G. Simpson. An Introduction to BotanyA. W. Haupt.

Macmillan \& Co., Ltw. Food Facts and Diet Planning -Grace Macdonald.

Thomas MURBY \& Co. German-English Botanical Terminology-Drs. E. and M. Ashby and Drs. Richter and Bärner.

Grorge Philip \& Son, Lrd. E. S. Heredity Charts, published for the Eugenics Society.

OXford UNIVERSiTy Press. Wild Flowers of Attica - the late S. C. Atchley. Index Kewensis, Supp. ixSir Arthur Hill.

Routledge \& Kegan Paul. British Caddis Flies (Trichoptera)-M. E. Mosely.

WARD, LOCK \& Co., LTD. British Flowering Plantsedited by A. K. Jackson. Varieties of British Butterflies-F. W. Frohawk.

H. F. \& G. Witherby, LTD. History of Sussex Birds-J. Walpole-Bond. Handbook of British Birds, vol. 2-H. F. Witherby, F. C. R. Jourdain, N. F. Ticehurst and B. W. Tucker. Birds of the Malay Peninsula, vol. 4-F. N. Chasen.

\section{Chemistry}

D. Appleton-Century Company, Experimental Procedures in General Chemistry-S. Morris and A. R. Collett. Chapman \& Hall, Lidd. Brewing: Science and Practice, vol. 2, Brewing Processes-L. Lloyd Hind. Introduction to the Chemistry of Cellulose-J. T. Marsh and Dr. F. C. Wood.

E. \& S. Livingstone. Chemical Analysis for Medical Students-Dr. R. E. Illingworth.

MoGraw-Hill Publishing Co., Litd. Colloidal Phenomena-E. A. Hauser. Theoretical Qualitative Analysis -J. H. Reedy.

MaCMILIAN \& Co., LTD. Guide to Chemical Laboratory Practice for Beginners-Prof. H. Bassett.

Oxford UnIVersity Press. An Introduction to Chemistry-J. C. Hogg.

University of London Press, Ltd. Fundamental Chemistry-H. Wilkins. 


\section{Engineering}

Edward Arnold \& Co. Tar Roads-A. C. Hughes, W. Gordon Adam and F. J. E. China.

G. BeLl \& Sons, LTd. Great Engineers-Prof. G. Matschoss. Geology for Engineers-Brig.-Gen. R. F. Sorsbie.

Chapman \& Hall, Ltd. Radio-Frequency Oscilla. tors-Dr. H. A. Thomas. Amplification and Distribution of Sound-A. E. Greenlees. Radio Cyclopaedia-G. Parr. Carburation and Carburettors in Theory and PracticeC. H. Fisher. Mechanies applied to Vibrations and Balancing-D. L. Thornton. Aircraft Design (2 vols.) C. H. Latimer-Needham. Stream and Channel FlowE. E. Morgan. Essentials of Reinforced Concrete Design -R. F. B. Grundy. Applications of the Rare Gases to Industry-J. T. Randall.

Crosby Lockwood \& Son, LTD. Surveying and Levelling-J. S. Terrington. The Producer Operator's Handbook-D. R. G. Crawford.

English Universitins Press, Ltd. Elementary Principles of Automobile Engineering-J. R. Kinsey. Stress and Strain Calculations for Structures-A. J. Chapple and R. McCrae. Fundamental Science for Building StudentsN. Howdill. Building Construction-E. G. Warland. McGraw-Hill Publishing Co., Ltd. Diesel Engineering-J. W. Anderson. Practical Designs for Drilling and Milling Tools-C. W. Hinman. Theory and Applications of Electron Tubes-H. Reich. Winding A.C. Motor CoilsG. A. Vanbrunt. Fractional Horsepower Motors-C. G. Veinott. Formulas for Stress and Strain-R. J. Roark. Macmillan \& Co., Ltd. Elementary Properties and Strength of Materials-J. A. Cormack and E. R. Andrew. Methuen \& Co., Ltd. A Textbook of Electrical Engineering-Prof. E. W. Marchant.

Oxrord UnIVersity Press. Elements of Radio Communication-O. E. Brown and E. L. Gardiner.

SIR IsaAc PItMan \& Sons, LTd. Faults and Failures in Electrical Plant-Prof. R. Spieser. Cathode Ray Tubes-Baron Manfred von Ardenne. Design of Welded Steel Structures-A. R. Moon. The Superheater in Modern Power Plant-D. W. Rudorff. Alternating Current Bridge Methods-Dr. B. Hague. Switchgear Handbook, vol. 1, Apparatus edited by W. A. Coates and H. Pearce. Electric Lifts-R. S. Phillips. Elementary Vectors for Electrical Engineers-C. W. Stubbings. Electric Circuits and Wave Filters-Dr. A. T. Starr. Processes and Machinery in the Plastics Industry-K. Brandenburger. Automobile Engineering-edited by $\mathrm{H}$. Kerr Thomas.

Charles Scribner's Sons, Ltd. What about the Airship ?-Commdr. C. E. Rosendahl.

E. \& F. N. Spon, Lmd. A.C. Motors of Fractional Horse Power-H. H. Jones.

\section{Geography and Travel}

Georae Axlen \& Unwin, Ltd. Travels in the North -K. Capek. Maltese Memories-E. Brockman. Un. climbed New Zealand-J. Pascoe.

B. T. Batsford, LTD. West Country-C. H. Warren A. \& C. Black, LTd. Peaks and Valleys-F. S. Smythe. ChatTo \& Windus. Southern Lights-J. Rymill.

Lhasa: the Holy City-F. Spencer Chapman.

Gerald Duckworth \& Co., Ltd. The Island of ZeusR. Brewster.

Hodder \& Stoughton, Ltd. Blank on the Map-

E. Shipton. The Lake of the Royal Crocodile-Eileen Bigland.

MaGraw-Hinl Publishing Co., Ltd. Elements of Cartography-Raisz.

Macmmlan \& Co., Ltd. Days in Old Spain-Gertrude Bone.

Ivor Nicholson \& Watson, Ltd. Himalayan QuestPaul Bauer.

Georae Philip \& Son, Ltd. Library Atlas of Physical, Political and Economic Geography-edited by G. Philip and Dr. H. C. Darby.

Putnam \& Co., Ltd. Diary of a Desert JourneyLord Gerald Wellesley. Alone-Rear Admiral R. E.
Byrd. Home by the Danube-D. Patmore. Exploring with Andrews: Selections for Younger Readers from the Writings of Roy Chapman Andrews.

Seeley, Service \& Co., Ltd. Treks and PalaversCapt. R. R. Oakley. White Hunter-J. A. Hunter. Frederick Warne \& Co., Ltd. Hills of LakelandW. H. Cooper.

\section{Geology}

D. Appleton-Century Company. Architecture of the Earth-Dr. R. A. Daly.

ChapMan \& HALL, LTD. Field Determination of Rocks-E. H. Davison.

Thomas Murby \& Co. The Geology of London and South Eastern England (Hampshire to Norfolk)-G. Macdonald Davies. Geology of China-Prof. J. S. Lee.

\section{Mathematics}

Cambridge University Press. The Geometry of Determinantal Loci-T. G. Room. Elementary Matrices, and some Applications to Dynamics and Differential Equations-F. A. Frazer, W. J. Duncan and A. R. Collar.

MaCMILlan \& Co., LTD. Advanced Algebra-S. Barnard and J. M. Child.

\section{Miscellany}

George Allen \& Unwin, Ltd. History of the Film-M. Bardeche and R. Brasillach. Writing and Action : a Documentary Anthology-compiled and edited by Mary Palmer. History of Science, Technology and Philosophy in the Eighteenth Century-Prof. A. Wolf. Builders of Health-D. Dietz. Power: a New Social Analysis-Bertrand Russell.

D. Appleton-Centurs Company. Science in General Education (report of the Committee on Science in General Education).

Cambridge University Press. Background to Modern Science-edited by Dr. J. Needham and W. Pagel. The Cambridge Region—edited by Dr. H. C. Darby.

VICTOR Gollancz, LTD. Leonardo da Vinci-Antonina Vallentin.

William Heinemann, Ltd. A Short History of Science -Dr. F. Sherwood Taylor.

MoGraw-Hill Publishing Co., Ltd. Introduction to Economic Statistics-W. I. Crum.

Routledge \& Kegan Paul. Social Function of Science-J. D. Bernal. Man and Society in the Age of Reconstruction-Karl Mannheim.

\section{Philosophy and Psychology}

George Allen \& Unwin, Ltd. The Marxist Philo. sophy and the Sciences-Prof. J. B. S. Haldane. Causality and Science-Dr. N. Brahma.

D. Appleton-Century Company. Fundamental Principles of the Metaphysic of Ethics-Immanuel Kant.

Cambridge University Press. Modes of Thought-

Prof. A. N. Whitehead.

University of London Press, Ltid. Psychological Methods of Healing-Dr. William Brown. The Factorial Analysis of Human Ability-Prof. G. Thomson.

Hogarth Press. Superstition and Society-Dr. R. Money-Kyrle.

MoGraw-Hill Publishing Co., Ltd. Psychological Factors in Marital Happiness-L. M. Terman. Psychological Foundations of Personality-L. P. Thorpe. Activi ties in the Elementary School-H. C. McKown. Education for Work-T. L. Norton. 
Methuen \& Co., Lto. Psychology, Philosophy and Religion-Prof. William McDougall. Actuality in School -G. J. Cons and Catherine Fletcher. The Human Problem in Schools-M. Milner. Play in the Infants' SchoolE. R. Boyce. A Short Commentary on Kant's Critique of Pure Reason-A. C. Ewing.

\section{Physics}

G. BeLl \& Sons, LtD. Light and Colour in the Open Air-Dr. M. Minnaert. Ultrasonies-Dr. Ludwig Bergmann. Electro-Acoustics-Prof. Erwin Meyer.

Blackit \& Son, Ltd. The Nature of Crystals-A. G. Ward. The Wave Nature of the Electron-G. K. T. Conn. The Perception of Light-Dr. W. D. Wright.

Cambridge University Press. The Mobility of Positive Ions in Gases-Prof. A. M. Tyndall. Superconductivity-D. Shoenberg. Electron Optics-O. Klemperer.

Chapman \& Hall, Ltw. Comprehensive Treatise on Atomic and Molecular Structure, vol. 3, Interpretation of Band Spectra-Dr. C. H. Douglas Clark. Electron Optics-L. M. Myers.

McGraw-Hill Publishing Co., Ltd. Principles of Electricity and Electromagnetism-G. P. Harnwell.

Macmillan \& Co., Ltw. Textbook of Heat-Prof. H. S. Allen and R. S. Maxwell.

MrTHUEN \& Co., LTD. A Textbook of ElectricityH. G. Mitchell. An Introduction to Vector Analysis for Physicists and Engineers-B. Hague. Fluorescence and Phosphorescence-E. Hirschlaff.
Oxford UnIversity Press. Spontaneous Fluctuations of Voltage due to Brownian Motions of Electricity and Kindred Phenomena-E. B. Moullin. Gaseous Electrical Conductors-Prof. E. L. E. Wheatcroft. Principles of Statistical Mechanics-Prof. R. C. Tolman.

\section{Technology}

Chapman \& Hall, Ltd. Photography by Infra-Red -Dr. W. Clark. Colour and Colour Reproduction (2 vols.) -H. D. Murray and Dr. D. A. Spencer. Non-Ferrous Foundry Practice-J. Laing and R. T. Rolfe.

Oxford University Press. Metals-Sir Harold Carpenter and Dr. J. M. Robertson. Structure of AlloysProf. W. L. Bragg.

McGraw-Hirl PUblishing Co., Lid. The Photographic Process-J. E. Mack and M. Martin. Fundamentals of the Petroleum Industry-D. Hager. Motion Pictures and Radio-E. Laine. Theory of Mechanical Refrigeration-N. R. Sparks. The Alloys of Iron and Nickel-J. S. Marsh.

Moray Press. Electricity and the Camera-H. Mortimer Batten.

Sir IsaAc PItMan \& Sons, Ltw. Welding of Cast Iron by the Oxy-acetylene Process-L. Tibbenham.

E. \& F. N. Spon, Limd. Humidity of the Air-C. L. Burdick. The Soybean Industry-Dr. A. A. Howarth. Technical Analysis of Ores and Metallurgical ProductsF. G. Hills.

Technical Press, Ltd. Refuse Destructors and Separation-A. W. Neal. 